http://dx.doi.org/10.15762/ZH.2017.71

JAN RATUSZNIAK

(University of Łodź)

\title{
Contact Between Alexandra Kollontai AND THe WALlenberg FAmily $(1930-1945)^{*}$
}

Key words: WWII, Sweden, the USSR, Finland, Raoul Wallenberg, the Winter War

The figure of Alexandra Kollontai (1872-1952) has enjoyed unabated popularity among the inhabitants of the Scandinavian states for many years. This is connected with her period of service as a diplomatic representative of the Soviet Union in Oslo and Stockholm in the stormy interwar period and during WWII. Alexandra Kollontai acted in many fields of contact between the Scandinavian countries and Moscow. She supported cultural and scientific exchanges. Her life abounded in mysterious events that are yet to be examined. Some of them concern her relations with an incredibly influential and wealthy Wallenberg family, whose most famous representative was a diplomat who saved thousands of people from the Holocaust - Raoul Wallenberg.

This article refers to the discourse of historians about the role which Alexandra Kollontai played in Soviet diplomacy and her relations with the Scandinavian countries. Polish literature on this subject matter contains a few texts, including one by Alicja Kiełbasiewicz and two articles written by the author

* This text was based on the basis of archival materials, printed sources and monographs acquired during the research financed by the Swedish Institute as part of the grant "The Relationship between Alexandra Kollontai and Wallenberg's family". The Author expresses his thanks to the scholars of Saint Petersburg University Prof. Walentyna Wieriemienko and Prof. Igor Tropov for the support provided during the research conducted in the Russian archives; and to Michał Turski M.A. for his help in translating from the German language. The article would not have been written had it not been for the precious remarks of Prof. Katarzyna JedynakiewiczMróz and Dr Kaare Hauge.

${ }^{1}$ Alexandra Kollontai animated trade exchange through various negotiations concerning commercial and cultural contacts while she was the diplomatic representative of the USSR in Norway and Sweden. Andrey V. RePNevSKIY, SSSR-Norvegiya: ekonomicheskiyeotnosheniya mezhvoyennogo dvadtsatiletiya, Arkhangel'sk 1998 [Андрей В. Репневский, СССР-Норвегия: экономические отношения межвоенного двадиатилетия, Архангельск 1998], pp. 15-17. 
of this paper. Still, there are no studies devoted to the relations between Alexandra Kollontai and the Wallenbergs. The author of the Polish biography of Raoul Wallenberg - Andrzej Sielski - devoted only one paragraph to the Soviet ambassadress. The authors of the articles about Wallenberg - Paweł Jaworski and Krystyna Pirogowicz - acted in a similar way. In the context of the peace talks between Finland and the USSR during WWII, Andrzej Kastory wrote several pages about Marcus Wallenberg Jr., ${ }^{2}$ Raoul's uncle. ${ }^{3}$

The issue of Alexandra Kollontai's relations with the Wallenberg family was much better presented in foreign historiography, mainly by Scandinavian scholars such as Kaare Hauge. Next, such issues were developed by Ulf Olsson in his biography on Marcus Wallenberg. ${ }^{4}$

The reports of the Swedish state committees of the 1990s dealing with the case of the abduction and detainment of Raoul Wallenberg in the USSR contribute the most to the subject matter. The Scandinavian scholars had access to archives both in Stockholm and in Russia. It must be underlined that they focused on the diplomat, not on Alexandra Kollontai. The same was true for the work of the Russian scholar Lew Bezymienski. However, he managed to access some unknown accounts given by Soviet intelligence service employees from Scandinavia. ${ }^{5}$

Alexandra Kollontai's biographers were quite reluctant to deal with the question of her relations with the Wallenberg family. In the case of the Soviet historians, this may be explained by the prohibition on writing about the history of Raoul as he had been kidnapped by Stalin's agents from Budapest. It was not until the end of the USSR's existence in 1990 that Mikhail Olesin

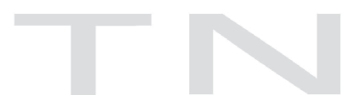

${ }^{2}$ Marcus Wallenberg, Jr. (1899-1982) - Swedish banker and industrialist, during WWII he cooperated with the German democratic opposition.

${ }^{3}$ Krystyna Pirogowicz, Co się stało z Raoulem Wallenbergiem? Losy zaginionego dyplomaty $w$ świetle najnowszych badań, Zapiski Historyczne, vol. 73: 2008, no. 1, pp. 83-97; Paweł JAWORSKI, Raoul Wallenberg - co nowego?, Dzieje Najnowsze, vol. 44: 2013, no. 3, pp. 121-129; Andrzej Kastory, Finlandia w polityce mocarstw1939-1940, Kraków 1993; idem, Złowrogie sqsiedztwo. Rosyjska polityka wobec europejskich państw ościennych w latach 1939-1940, Kraków 1998.

${ }^{4}$ Kaare Hauge, "Alexandra Kollontai - The Scandinavian Period", Minnesota 1971 (unpublished $\mathrm{PhD}$ thesis); Ulf Olsson, Furthering a Fortune, Marcus Wallenberg. Swedish Banker and Industrialist 1899-1982, Stockholm 2001.

${ }^{5}$ The first report was prepared by the Swedish-Russian group of researchers. The second one was based on the archival materials of the Swedish Ministry of Foreign Affairs. Raoul Wallenberg. Redosvisningen från den svensk-ryska arbetsgruppen, Stockholm 2000; Ett diplomatiskt misslyckande. Fallet Raoul Wallenberg och den svenska utrikesledningen, Stockholm 2003; Lev A. Bezymensкiy, Budapeshtskaya missiya. Raul' Vallenberg, Moskva 2001 [Лев А. Безыменский, Будапештская миссия. Рауль Валленберг, Москва 2001]. 
mentioned Alexandra's meeting with Marcus, but he did not develop the story. Later, Lew Bezymienski touched upon the issue of contact between the Soviet ambassadress and Raoul. Other Russian scholars who examined her history did not address this particular issue. This might have been caused by the language barrier or the impossibility of accessing new documents (the most important studies and documents are available only in Swedish). ${ }^{6}$

For years, Anglo-Saxon biographers of Alexandra Kollontai such as Cathy Porter, Beatrice Farnsworth and Barbara Evans Clements did not address the issue of Kollontai's relations with the Wallenberg family. Probably this resulted from a lack of access to source materials and the language barrier. Cathy Porter referred to the issue in the most recent edition of her book about the famous revolutionary. However, she made a huge mistake as she combined the figures of Marcus and Raoul into one person. According to the British scholar, Raoul stayed in Budapest and at the same time he ran unofficial peace talks between the USSR and Finland in Stockholm.?

This article was written in order to fill in the gap in Polish historiography and to refer to the international discourse devoted to Alexandra Kollontai's relations with the Wallenberg family in the discussed period.

During the analysis of those affiliations the following questions arise: When did Alexandra Kollontai initiate contact with the Wallenberg family? Whom did she meet? What were the reasons for the meetings? How did the talks end? Did they really influence the events of WWII? Did the meeting of the Swedish diplomat with his Soviet counterpart affect the reality of post-war Europe? The chronological frameworks of the article are demarcated by two years - the first and the last contact between the members of the Wallenberg family with Alexandra Kollontai. The source base consists in materials found in the following archives: Riksarkivet, the Archive of Göteborg, the Russian State Archive of Social-Political History (RGASPI), the Central State Archive of Literature and Art of Saint Petersburg (CGALISP). The diaries written by Alexandra Kollontai, ${ }^{8}$ the

${ }^{6}$ Mikhail I. Olesin, Pervaya v mire. Biograficheskiy ocherk ob A. M. Kollontay, Moskva 1990 [Михаил И. Олесин, Первая в мире. Биографический очерк об А. М. Коллонтай, Москва 1990]; Mikhail Trush, Ot politiki revolyutsionnoy bor'by k pobedam na diplomaticheskom fronte: zhiznennyy put' Aleksandry Kollontay: „Zolotaya vetv' diplomatii Rossii”, Moskva 2013 [Mихаил Труш, От политики революиионной борьбы к победам на дипломатическом фронте: жизненный путь Александры Коллонтай: „Золотая ветвь дипломатии России”, Москва 2013]; L. A. BeZYMENSKiY, op.cit., pp. 4, 11, 65.

${ }^{7}$ Cathy Porter, Alexandra Kollontai, London 2014, p. 443.

${ }^{8}$ Aleksandra M. Kollontay, Diplomaticheskiye dnevniki: 1922-1940, vol. 1-2, Moskva 2001 [Александра М. Коллонтай, Дипломатические дневники: 1922-1940, т. 1-2, Москва 2001]. 
Finnish politicians Juho Paasikivi ${ }^{9}$ and the memoirs of the Soviet agent Jelisiej Sinicyn ${ }^{10}$ also played a major role.

The attempt to answer the questions connected with Alexandra Kollontai's relations with the Wallenberg family should begin with an outline of the beginnings of the career of this representative of the Soviet diplomacy. In 1930 the Soviet embassy in Sweden experienced some serious problems. The diplomatic representative of the USSR ("połpried", “полпред") ${ }^{11}$ Wktor Kopp ${ }^{12}$ fell ill with cancer, which made it impossible for him to continue his service. He died in 1930. Soon after his death his deputy, Sergiusz Dmitrijevskij was summoned to Moscow. However, he refused to execute this order and asked the Swedish authorities for political asylum while criticizing the Soviet reality. The diplomatic post in Stockholm could not remain vacant for too long; that is why the People's Commissar of Foreign Affairs of the USSR Maksym Litwinow decided to send an experienced diplomat there - Alexandra Kollontai. ${ }^{13}$

It was understandable to entrust the office to Alexandra Kollontai. She had maintained contact with the Scandinavian countries. From her childhood she had been closely linked with Finland - the country of origin of her mother's family - the Masalins. The summer residence of her parents also was situated near Vyborg, which was inhabited by the Finns. For this reason, she could speak Swedish; in her childhood she had frequently visited Stockholm. ${ }^{14} \mathrm{Her}$ father, Michał Domontowicz, had Polish roots, but her daughter was not interested in this part of the family tradition despite the fact that she married her cousin Włodzimierz Kollontai - a son of a participant of the January Uprising. They had one child - a son Michal, who was born in 1898. At the beginning of the $20^{\text {th }}$ century Alexandra left her husband and started a political career. Until

\footnotetext{
${ }^{9}$ Juho K. PaAsikivi, J. K. Paasikivi dägboker 1941-1944. Samtal i ond tid, Stockholm 1991.

${ }^{10}$ Yelisey Sinitsyn, Rezident svidetel'stvuyet, Moskva 1996 [Елисей Синицын, Резидент свидетельствует, Москва 1996].

11 "Połpried", “полпред” - ru. "Чрезвычайный и полномочный посол”. The representative of the Soviet diplomacy abroad, the equivalent of ambassador. In 1943 the USSR returned to the pre-revolutionary nomenclature.

${ }^{12}$ Wiktor Kopp (1880-1930) - a member of the Bolshevik party. The trade representative (“торгпред") in Germany, later, in the years 1925-1927, “торгпред” in Japan, and from 1927 until his death - the diplomatic representative of the USSR in Sweden.

${ }^{13}$ Emma Lorentson, A. M. Kollontay v Shvetsii, Novaya i Noveyshaya Istoriya, 1966, no. 1 [Эмма Лорентсон, А. М. Коллонтай в Швеции, Новая и Новейшая История, 1966, но. 1], p. 105.

${ }^{14}$ The considerable part of the Finish elites spoke Swedish in their everyday contacts Matti Klinge, Imperskaya Finlyandiya, Sankt-Peterburg 2005 [Матти Клинге, Имперская Финляндия, Санкт-Петербург 2005], pp. 267-272.
} 
the beginning of WWI she was a member of the Mensheviks and the German Social-Democrats (SPD). Her political ideas significantly affected the Russian and West-European women's movement, particularly the thesis about the impossibility of the cooperation between the socialists and suffragists owing to different class interests represented by both of those groups. She also researched human sexuality. ${ }^{15}$ Shocked by the atrocities of the war in 1915 she supported Vladimir Lenin and the Bolsheviks as they advocated internationalism. She quickly became one of the most important party activists. During the Russian Revolution of 1917 Alexandra Kollontai started to cooperate with the Swedish and Finnish socialist movements; she also got to know their leaders. Apart from foreign contacts, her great advantage was political and diplomatic experience. After the Bolsheviks had assumed power, she held the office of the people's commissary for social affairs for several months. She also held other official functions. Owing to a conflict with Lenin about the shape of the political system of the state, she was dismissed. ${ }^{16}$ When Stalin strengthened his position at the beginning of the 1920s, he gave her some new tasks, which was probably an expression of thanks for having given Stalin Lenin's critical letters about Leon Trotsky. ${ }^{17}$ She became the first woman to hold the post of a diplomatic representative. In the years 1922-1926 she stayed in Norway; next, she represented Moscow in Mexico for a short time. In 1927 she returned to Oslo, and in 1930 she was relocated to Stockholm..$^{18}$

Alexandra Kollontai held a strong position compared with other diplomats staying in Oslo. Prior to the outbreak of WWI, she supervised the trade talks between Sweden and the USSR. She also made an effort to develop the cooperation in the cultural and scientific field between those two countries. Thanks to her personal charm, Alexandra managed to establish numerous contacts with the Swedish elite. ${ }^{19}$

${ }^{15}$ Comp. Jan Ratuszniak, Russkiye, Polyaki, Finny? Etnicheskaya identichnost' sem’i Aleksandry Kollontay [Русские, Поляки, Финнь? Этническая идентичность семьи Александры Коллонтай], [in:] Vade Nobiscum. Materiały Studenckiego Koła Naukowego Historyków Uniwersytetu Łódzkiego, vol. 13, ed. Konrad Banaś, Robert Stasiak, Łódź 2014, pp. 259-266.

${ }^{16}$ Alexandra Kollontai supported the Workers' Opposition, the faction of the Bolshevik party which was against bureaucracy, the New Economic Policy and the marginalization of workers and trade unions (Richard PIPes, Rosja Bolszewików, Warszawa 2007, pp. 479-481).

${ }^{17}$ Marcel Body, Alexandra Kollontai, Preuves 1952, no. 14, p. 18.

${ }^{18}$ Lilianna ŚwiateK, Aleksandra Kołłontaj na placówce w Meksyku (1926-1927), Acta Universitatis Lodziensis. Folia Historica, no. 76: 2003, pp. 113-130.

${ }^{19}$ Naturally, Alexandra Kollontai had to execute orders sent to her by Moscow Oleg KeN, Aleksandr Rupasov, Lennart SAmuyel'son, Shvetsiya v politike Moskvy 1930-1950-ye gody, Moskva 2007 [Олег Кен, Александр Рупасов, Леннарт Самуельсон, Швеиия в политике Москвы 1930-1950-е годы, Москва 2007], pp. 339-361; K. HAUge, op.cit., pp. 166-167. 
Undoubtedly, the Wallenbergs belonged to a group representing the Swedish elite. This family was one of the richest and most influential in Scandinavia. Their origins date back to the $17^{\text {th }}$ century, but they became powerful in 1856 when they established Stockholms Enskilda Bank (SEB). It quickly became the biggest Swedish investment bank. Along with its development, the status of its owners rose. Knut Agathon Wallenberg (1853-1938) was a Member of Parliament - Riksdag and the Minister of Foreign Affairs of Sweden in the years 1914-1917. In the interwar period, the heads of the Wallenberg clan were Jacob and Marcus Wallenberg. They were known as excellent economists. The evidence of this was their participation in the works of the group of the American economist Owen Young, ${ }^{20}$ which was responsible for Germany's war reparations for WWI. Although the activities of the group fell through, the Swedish businessmen made contact with the establishment of the Weimar Republic and the financial world. ${ }^{21}$

Alexandra Kollontai met the Wallenbergs for the first time at the beginning of the 1930s. The USSR sought the return of the gold deposited in the spring of 1917 in SEB. Naturally, the owners of the bank objected to returning the resources. ${ }^{22}$

In 1930 Alexandra Kollontai got in touch with SEB officially asking the bank to return millions of Swedish krona to the USSR. The representatives of the bank refused to do so, justifying their decision with various legal reservations. According to the information given by the authorities of the financial institution, the deposited resources had not been transferred via the National Bank of Russia, but from the Private Bank of Azov-Don, which was liquidated after the October Revolution of 1917. SEB was only in a position to pay out the resources to anyone granted power of attorney by the defunct bank. ${ }^{23}$

Wanting to check whether it was possible to settle the case with the owners of SEB, Alexandra Kollontai decided to meet them. She had an unofficial conversation with Marcus Wallenberg Sr. ${ }^{24}$ which took place in mid-1930. He no longer administered the bank, but still advised its authorities. During the short conversation it turned out he hated communism. Ignoring the rules of diplomatic etiquette he stated that: "The Russians may be a nation of good

${ }^{20}$ Owen Young (1874-1962) - American economist, businessman, lawyer and political activist; he participated in the negotiations concerning the magnitude of German indemnities for WWI in 1929.

${ }^{21}$ Jacob Wallenberg (1892-1980) - Swedish businessman and tennis player. He was the director of Enskilda Bank for many years.

${ }^{22}$ A. M. KollontaY, op.cit., vol. 2, pp. 170-171; K. HaUge, op.cit., p. 166.

${ }^{23}$ A. M. KollontaY, op.cit., vol. 2, pp. 170-171.

${ }^{24}$ Marcus Wallenberg, Sr. (1864-1943) - Swedish banker, officer of the navy, the director of SEB until 1920. His company was taken over by his sons Jacob and Marcus Jr. 
philosophers, but in economic-financial matters we [the Swedes - J.R.] are «fantabulous»". ${ }^{25}$ When Alexandra Kollontai tried to manipulate him with her traditional tactics of charming the Scandinavian elites with possible Soviet investments in Sweden, he responded: "You cannot buy me". ${ }^{26}$ The conversation ended at this point.

To Alexandra Kollontai's surprise, one of the sons of Marcus Wallenberg Jacob contacted her the next day. He did not exclude the possibility of further negotiations and tried to soothe the negative impression made by his father. In this situation Alexandra managed to "convince" SEB with a financial argument. Soon most of the money connected with the trade exchange between Sweden and the USSR was entrusted to the representatives of this bank. ${ }^{27}$

Alexandra Kollontai also decided to use Swedish businessmen for her own purposes, who, unlike the Wallenbergs, were interested in trade with the Soviet Union. ${ }^{28}$ In the face of the persistent economic crisis the Swedish interest in exporting to this country was enormous. In 1932 the socialists won the parliamentary elections; Per Albin Hansson became Prime Minister, ${ }^{29}$ and the Minister of Foreign Affairs - Rickard Sandler. ${ }^{30}$ Alexandra knew both of them. The new cabinet persuaded the Wallenbergs to change their strategy. SEB returned the gold to the USSR in exchange for covering the costs of the maintenance of the gold ingots since 1917. Kremlin agreed to give back part of the deposit to Sweden to pay off the debts of the Russian Provisional Government. Following the above-mentioned arrangements, the Kremlin achieved its objective, while Kollontai chalked up another diplomatic success. ${ }^{31}$ In contrary to what the historian K. Hauge claims, she did not receive the Order of Lenin for her successful operation. ${ }^{32}$ She was decorated for her diplomatic work as a whole. ${ }^{33}$

${ }^{25}$ A. M. KollontaY, op.cit., vol. 2, pp. 40-41.

${ }^{26} \mathrm{Ibid}$.

${ }^{27}$ Ibid., pp. 42-43, 48.

${ }^{28}$ Raoul Wallenberg. Redosvisningen från den svensk-ryska arbetsgruppen, p. 120; U. OLsson, op.cit., pp. 5-60; Håkan Lindgren, Jacob Wallenberg 1892-1980, Stockholm 2007, pp. 81-83.

${ }^{29}$ Per Albin Hansson (1885-1946) - Swedish politician, from 1925 the head of SAP, for many years the Minister of Defence of Sweden, from 1932 until his death he was the Prime Minister of Sweden.

${ }^{30}$ Rickard Sandler (1884-1964) - Swedish politician, socialist, the Minister of Trade in 1920, the Prime Minister in the years 1925-1926, the Ministry of Foreign Affairs in the years $1932-1939$.

${ }^{31}$ A. M. Kollontay, op.cit., vol. 2, p. 171.

${ }^{32}$ She received the prestigious distinction for this - the Order of Lenin - established by the Presidium of the Central Executive Committee of the USSR in 1930; it was the highest civil decoration in the USSR.

${ }^{33}$ A. M. Kollontay, op.cit., vol. 2, p. 143; K. Hauge, op.cit., p. 166. 
Scholars vary in their opinion as to the attitude of Marcus and Jacob towards communist Moscow. They must have been more flexible than the older generation of the clan. Vadim Birstein, the author of a monograph devoted to the Soviet branch of the military secret service, suggested that from the early 1920s their company traded with the USSR on a massive scale. Scholars from the Swedish-Russian working group ${ }^{34}$ examining the history of Raoul Wallenberg thought that SEB had started to sell parts to airplanes on a small scale during WWII. The thesis about the clan's minor involvement in this profitable trade with the USSR was confirmed by the biographers of Marcus and Jacob - Ulf Olsson and Håkan Lindgren. According to them, they were involved in businesses in Western Europe - mainly in Germany and the USA. Interestingly, the Wallenbergs, among other foreign languages, also spoke fluent Russian. ${ }^{35}$

The entries in Kollontai's diary and her correspondence with her physician Ada Nilsson ${ }^{36}$ confirm the development of Kollontai's contacts with the Wallenbergs before WWII. Alexandra spent her holidays in a hotel belonging to Marcus and Jacob's clan. It was situated near the well-known sanatorium of Saltsjöbaden, where the ageing Russian diplomat cured her heart problems. The Wallenbergs stayed in the hotel from time to time. However, it is hard to establish the nature of their relationship on the eve of the outbreak of the war. ${ }^{37}$

The relationship between the Wallenbergs and Alexandra Kollontai before the outbreak of WWII was tense. Stalin dismissed Litvinov from the position of the people's commissary for foreign affairs. Even before the dismissal of this experienced commissary, the purges had started in the diplomatic apparatus of the Soviet Union. Only two people were not dismissed - Alexandra Kol-

${ }^{34}$ The Swedish-Russian working group consisting of historians and diplomats, was set up by the governments of Sweden and the USSR (later the Russian Federation) in September 1991 in order to explain what had happened to Raoul Wallenberg. The team finished their work in 200 publishing the report presenting their findings. The teams consisted of Hans Magnusson, Martin Hallqvist, Jan Lundvik, Björn Lyrvall, Krister Wahlbäck, Lage Olson, Krystian Gemem, Dymitr Wołkogonow, Rudolf Pichoja and Anatolij Prokopenko. Raoul Wallenberg. Redosvisningen från den svensk-ryska arbetsgruppen, pp. 12-16.

${ }^{35}$ Vadim J. Birstein, Smiersz. Tajna broń Stalina. Sowiecki kontrwywiad wojskowy podczas II wojny światowej, Kraków 2013, p. 49; Raoul Wallenberg. Redosvisningen från den svensk-ryska arbetsgruppen, p. 76; U. Olsson, op.cit., pp. 5-60; H. LINDGREN, op.cit., pp. 81-83.

${ }^{36}$ Ada Nilsson (1872-1964) - a medical doctor and activist of the Swedish women and pacifist movement. She dealt with the question of sexuality; she also published periodicals for women.

${ }^{37}$ Göteborgs Universitetbibliotek (GU), Aleksandra Kollontaj' Letters to Ada Nilsson, 4.10.1936; 12.07.1937; 13.09.1938; 3.04.1939; no entry number; A. M. KollontAY, op.cit., т. 2, p. 438. 
lontai and Ivan Majski. Yet, Kollontai did not feel secure. She felt she could be summoned to Moscow any time and be sentenced to death or a long term of imprisonment. The same could happen to her family. In the event of the outbreak of the war, her son could be recruited to the army. She did not have good relations with Litvinov's successor - Vyacheslav Molotov. She was scared when observing the ties between the USSR and the Third Reich tighten. She considered the Molotov-Ribbentrop Pact to be a huge mistake. ${ }^{38}$

The Wallenbergs, like Alexandra Kollontai, feared the outbreak of the war. It was not clear whether Sweden would manage to keep neutrality. Many of the Wallenbergs' businesses were located in the territories of the Third Reich, Belgium and Holland. Plants and goods might be destroyed due to military operations. ${ }^{39}$

When WWII broke out she was staying in Stockholm after returning from Norway, where she had supervised the transportation of Soviet gold from Norwegian banks to Great Britain. Although in her memoirs she was critical of Stalin's foreign policy, she officially supported it. She was not particularly moved by the Soviet annexation of the Polish eastern territories and the Baltic States, but she was very worried about the plight of Finland. On 12 October the USSR decreed that the border with Finland be moved by 25 kilometres and the Peninsula of Hanko be rented to them. The Finnish government refused their demands. On 26 November 1939 the Soviet-Finnish war broke out. ${ }^{40}$

Alexandra Kollontai was devastated with the fact that the Soviet Union had attacked Finland. She knew that the country she was emotionally attached to might fall off the map. When the war broke out, her status as a diplomat decreased as she had lost her main asset - relations with the Swedish elites. Many of the people who had cooperated with her earlier, now broke off all contact with her. Alexandra did not just worry about herself, but also about her son and family. She wanted them to come to Sweden. Had she lost her position, so her closest family would have borne the consequences. That is why she had to be cautious in her dealings with Moscow. ${ }^{41}$

${ }^{38}$ Sabin Dyullen, Stalin i yego diplomaty. Sovetskiy Soyuz i Yevropa. 1930-1939 gg., Moskva 2009 [Сабин Дюллен, Сталин и его дипломаты. Советский Союз и Европа. 1930-1939 г2, Москва 2009], p. 260; A. M. Kollontay, op.cit., vol. 2, p. 455.

${ }^{39}$ H. LINDGREN, op.cit., p. 112.

${ }^{40}$ A. M. Kollontay, op.cit., vol. 2, p. 454; Andrzej Kastory, Finlandia w polityce mocarstw 1939-1940, Kraków 1993, pp. 25-30, 49-55.

${ }^{41}$ Michal Kollontai came to Sweden with his wife and son at the beginning of 1940 (A. M. KollontaY, op.cit., vol. 2, pp. 444, 461; Rossiyskiy gosudarstvennyy arkhivsotsial'no-politicheskoy istorii, F. 134, op. 3, yed. khr. 78; Vladimir M. Kollontaj, Minnen Av famor, [in:] Revolusjon, kjaerlighet, diplomati. Alexandra Kollontaj og Norden, red. Yngvild Sørbye, Oslo 2008, pp. 33-36. 
The Wallenbergs were not content with the outbreak of the war. Unlike Kollontai, they were involved in the conflict to a much greater extent. Marcus and Jacob quickly became informal advisors to the Swedish authorities in economic matters. Marcus represented Stockholm in the talks with great Britain in the autumn of 1939, which ended with the signing of profitable trade deals. Apart from this, he cooperated with the British elites. Like them, he hated the Nazis. However, it must be stressed that Jacob cared for the family businesses in the Third Reich despite the fact that in the first months of the war he established cooperation with anti-Hitler opponents such as Carl Goerdeler ${ }^{42}$ and Robert Bosch. ${ }^{43}$ He transmitted the information acquired from the German opposition to London. The brothers were anxious about the threat from the USSR. The annexation of the Baltic States constituted a serious danger to Swedish economic and military interests, but Stalin's assumption of control over Finland could terminate the country's independence. ${ }^{44}$

The desire to end the winter war peacefully and to ensure Finland independence from the Soviet Union was what united Marcus and Jacob Wallenberg and Alexandra Kollontai. Obviously, their motivation was different. Alexandra was driven by a sentiment for her motherland; she also wanted to strengthen her position - now impaired after the dismissal of Litvinov. The Swedish businessmen intended to protect Sweden against the direct proximity of the Soviet Union.

The Wallenbergs was advocates of Sweden becoming more involved in Finland, particularly through diplomatic action. Surprisingly, Marshal Carl Gustav Mannerheim's army of defended Finland successfully, which gave Sweden time to intensify diplomatic operations. Marcus and Jacob were among the people who persuaded the government in Stockholm to tolerate unofficial peace talks between Alexandra Kollontai and the Finnish writer Hella Wuoljoki ${ }^{45}$ in January 1940. The talks held with the mediation of Sweden eventually led to the conclusion of peace on 12 March 1940. The conditions of the peace agreement were very tough for Helsinki: the USSR received the Karelian Isthmus along with Vyborg, the western and northern coast of Lake Ladoga

${ }^{42}$ Carl Goerdeler (1884-1945) - German politician and activist of anti-Nazi opposition. He was executed in the assassination on 20 July.

${ }^{43}$ Robert Bosch (1861-1942) - German industrialist and philanthropist. He was against the Nazis; along with his co-workers he helped the Jews in the Third Reich

${ }^{44}$ H. Lindgren, op.cit., pp. 265-283; U. Olsson, op.cit., p. 211; John Gilmour, Sweden, the Swastika and Stalin. The Swedish Experience in the Second World War, Edinburgh 2012, pp. 127-128.

${ }^{45}$ Hella Wuoljoki, pen name Hella W. (1886-1956) - Finish writer and left-wing activist. After WWII she was the head of the public media until 1947. 
including the towns situated there. The Finnish government agreed to leasing the Peninsula of Hanko for 30 years. In total, Finland lost $10 \%$ of its territory. ${ }^{46}$

Despite mutual effort to end the winter war, we do not know anything about Alexandra Kollontai's relations with Marcus and Jacob, or other members of the Wallenberg family during the time of the conflict between the Soviet Union and Finland at the turn of 1939-1940. Probably there were many people who were willing to play the role of peace emissaries. ${ }^{47}$

After the Third Reich attacked the USSR on 22 June 1941 the situation changed when Finland joined the military operation, but only in order to regain its lost territories. Paradoxically, the effect of the German invasion on the USSR was a more significant role for Ada Kollontai as a Soviet diplomat in Stockholm who, being situated on the neutral area, could establish talks with ambassadors of the Axis Powers. The Wallenbergs did not share the fascination with the German offensive in the USSR. Marcus went to Finland; he also stayed in the territory which recently had been occupied by the Red Army. Frightened by what he saw in Vyborg, he decided to aim at another peace agreement between Helsinki and Moscow. ${ }^{48}$

In the first months of the war, neither the Finnish government nor Stalin were interested in the concluding a peace treaty. Still, Alexandra Kollontai and Marcus Wallenberg were determined to commence the peace negotiations.

Scholars have not been unanimous about who was the first to suggest the peace talks - the Swedish businessman or Alexandra Kollontai? Russian scholars maintain that it was Alexandra who initiated the talks, while Scandinavian historians indicate Marcus. In the archival material of the Swedish secret service, which has been recently declassified, there are transcripts of overheard conversations from the Soviet diplomatic post. They reveal that Alexandra Kollontai was the first to request the meeting. ${ }^{49}$

It should be underlined that after some time, the great powers strove to end the Soviet-Finnish war. The British supported the activities of Marcus Wallen-

${ }^{46}$ U. Olsson, op.cit., p. 212; Andrzej Kastory, Złowrogie sąsiedztwo. Rosyjska polityka wobec europejskich państw ościennych w latach 1939-1940, Kraków 1998, pp. 84-87, 95-96.

${ }^{47}$ A few countries refused to hold peace talks between Finland and the USSR, including the Third Reich (A. Kastory, Finlandia w polityce mocarstw, pp. 84-86).

${ }^{48}$ The Swedish elites were enchanted with the successes of the Third Reich in the first months of the war with the USSR. It was common to express one's joy with the losses of communists. See more in: Staffan Thorsell, Mein lieber Reichskanzler! Sveriges kontakter med Hitlers rikskansli, Oslo 2007; Vladimir I. JerofeJEv, Vid den sovjetiska ambassaden i Stockholm 1942-1945, [in:] Revolusjon, kjaerlighet, diplomati. Alexandra Kollontaj og Norden, pp. 138-139.

${ }^{49}$ M. I. Olesin, op.cit., p. 341; M. Tpyш, op.cit., p. 422; K. Hauge, op.cit., p. 240; phone call from 5. Mai 1941 (Riksarkivet, P753, löp 2, 193). 
berg. Stalin also believed that it was more beneficial for him to end the conflict; the Swedish authorities were also interested in the success of the negotiations. ${ }^{50}$

Marcus Wallenberg got in touch with Juho Paasikivi, ${ }^{51}$ one of the few Finnish politicians who did not believe in the victory of Germany over the USSR. In December 1941, the Swedish banker, the former ambassador in Moscow, and A. Kollontai met for the first time. Their meetings took place regularly throughout the next few years. Interestingly, all the costs connected with the guests' stay were covered by SEB. The former Finnish Minister of Finance stated that Marcus and Alexandra had made friends, but they were still tough in their negotiations. He suspected that they met without him. Employees of the Soviet embassy confirmed that M. Wallenberg and A. Kollontai often contacted each other. According to their entourage, their relationship could be referred to as a friendship although for their part it could still be just a refined game. The evidence for this is the fact that Kollontai, despite her sympathy, passed reports concerning Marcus's political moves towards Moscow. ${ }^{52}$ Some meetings took place outside Stockholm, in Saltsjöbaden. It should be underlined that Marcus Wallenberg made efforts to make Alexandra Kollontai feel comfortable as she was partly paralysed after a heart attack in May 1942 and was confined to a wheelchair. ${ }^{53}$

Diplomatic talks intensified at the beginning of 1944. For all the parties it was clear that the defeat of the Third Reich was only a matter of time. The Finnish authorities wanted to withdraw from the war as quickly as possible. The Soviet spy and embassy worker in Stickholm, Jelisiej Sinicyn, ${ }^{54}$ mentioned that Marcus Wallenberg, on Alexandra Kollontai's request, passed the peace offerings put forward by Stalin directly to Helsinki. The Swedish businessman arranged direct meetings between Alexandra Kollontai with Paasikivi. Kollontai participated in the final peace talks. ${ }^{55}$

${ }^{50}$ J. Gilmour, op.cit., pp. 94-98.

${ }^{51}$ Juho Paasikivi (1870-1956) - Finish politician, professor of law and history. In the years 1908-1909 was the Minister of Finance in independent Finland. In the years 1936-1939 he was the ambassador of Finland in Stockholm, and in 1941 he represented Helsinki in the USSR. In the years 1944-1946 he was again the Prime Minister of Finland, and in 1946 he took the office of president, which he held until 1956.

${ }^{52}$ J. K. PAASIKIVI, op.cit., pp. 133-136, 284-287; Raoul Wallenberg. Redosvisningen från den svensk-ryska arbetsgruppen, p. 61.

${ }^{53}$ K. Hauge, op.cit., p. 244; J. K. PaAsikivi, op.cit., p. 217.

${ }^{54}$ Jelisiej Sinicyn (1909-1995) - a resident of the NKWD in Poland in 1939; during WWII he dealt with the intelligence service in Finland, where he was officially introduced as a diplomat. From August 1943 he stayed in Stockholm. After WWII he supervised the networks of spies in the countries of Central and East Europe.

${ }^{55}$ E. Sinitsyn, op.cit., pp. 164-167. 
As a result of the talks of 19 September 1944, Finland signed a truce with the USSR. The peace treaty was not signed until 1947. Moscow again received the territories conquered after the Winter War and the small piece of land situated on the Pechenga River. Helsinki agreed to lease the Peninsula of Porkkalanniemi for 50 years to the Soviet Union and to conduct its foreign policy in accordance with the USSR. ${ }^{56}$

The final stage of WWII was the most mysterious period in the relations between Alexandra Kollontai and the Wallenbergs. If their participation in the peace talks between Finland and the USSR has been quite well presented in numerous publications, the subsequent events were shrouded in mystery due to the lack of access to archival materials in the USSR.

The cooperation between Alexandra Kollontai with the Wallenbergs developed not only politically, but also socially and economically. According to many archival sources generated by Soviet journalists staying in Sweden, charity organizations supported by some Swedish capitalists sent gifts for orphans from the Soviet Union. Among them there were also organizations supported by Marcus and Jacob. ${ }^{57}$

In 1944, trade talks between the USSR and Sweden were held. Officially, the Wallenbergs did not take part in them; the Stockholm capitalists were represented by Axel Jonsson. ${ }^{58}$ At that time the most famous representative of the Wallenberg family, Raoul Wallenberg, was staying in Sweden. For some unknown reasons, the secretary of the embassy of Sweden in Budapest, where he saved people of Jewish origin from death, met Alexandra Kollontai before his departure to Hungary. It is also known that he talked with Marcus at the same time. ${ }^{59}$

We do not know what Raoul talked about with Alexandra. It is possible that his family tried unofficially to establish broader trade deals with the Soviet Union. However, had this been the case, the negotiations would have been held by much more experienced businessmen - Marcus or Jacob - and not by their nephew. Jelisiej Sinicyn in his memoirs suggested that the Swedish diplomat was to become a Soviet spy. The question arises as to why he was to collect his orders in Stockholm. Lew Bezymienski rejected such a possibility on the basis of what Soviet spies had told him. The Scandinavian scholar Wilhelm Agrell suggested that Raoul cooperated with the American and British intelligence

${ }^{56}$ Barbara Szordy Kowska, Historia Finlandii, Warszawa 2011, pp. 321-330.

${ }^{57}$ Tsentral'nyy gosudarstvennyy arkhiv literatury i iskusstva Sankt-Peterburga, F. 293, op. 2, d. 1494, 1. 1. 107 [Центральный государственный архив литературы и искусства СанктПетербурга, Ф. 293, оп. 2, д. 1494, 1. 1. 107].

${ }^{58}$ Axel Jonsson (1888-1950) - Swedish banker and industrialist.

${ }^{59}$ Raoul Wallenberg. Redosvisningen från den svensk-ryska arbetsgruppen, p. 38. 
services, which would explain his journey to Stockholm and the conversation with his uncle. ${ }^{60}$

After some years, the wife of the Minister of Foreign Affairs of Hungary Gàbor Keméne, Erzésbet Kemény-Fuchs ${ }^{61}$ gave away one of the themes of the conversation between Wallenberg and the Soviet ambassador to some journalists from "Der Spiegel”. The Swedish diplomat promised to help Gàbor Keméne and his wife if they led to the Hungarian authorities' recognition of passports issued by the neutral states. In return, Gàbor was to avoid punishment for supporting Hungarian fascists. In October 1944, before Erzésbet left Budapest, Raoul was to have told her: "I talked about you with Mrs. Kollontai. [...] I asked her to help you and your child". ${ }^{62}$ As Lew Bezymienski wrote: we even do not know in what way the message was transmitted - by telegraph, letter or phone. The Russian researcher did not exclude the possibility that Wallenberg could have met Kollontai in person in Stockholm. Unfortunately, this cannot be established as long as there is no access to the Russian archives. ${ }^{63}$

The account of Erzésbet Kemény-Fuchs is evidence that Raoul Wallenberg considered Alexandra Kollontai to be trustworthy. We do not know what could have affected his judgement. It might have been the result of a direct meeting and a telephone conversation with Kollontai, or maybe it was the opinion of Marcus about Alexandra that most influenced his perception of the Soviet ambassadress.

The next events from the life of Raoul Wallenberg were closely connected with Alexandra Kollontai. In January 1945 the Swedish diplomat disappeared after Budapest had been overrun by the Red Army. Nobody could explain what had happened to him. Moscow maintained that they did not know anything about his whereabouts. ${ }^{64}$ The behaviour of Alexandra Kollontai was surprising. So far she had been loyal to Stalin. Even if she had doubts about the foreign policy of the USSR, she explained them during her meetings with Litvinov or Molotov. She tried to execute orders received from Moscow. However, when

${ }^{60}$ E. Sinitsyn, op.cit., p. 257; L. A. Bezymenskiy, op.cit., p. 78; Wilhelm Agrell, Skuggor runt Wallenberg, Lund 2006, p. 172.

${ }^{61}$ Gàbor Kemény (1910-1946) - Hungarian Minister for Foreign Affairs in the years 1944-1945. He cooperated with Raoul Wallenberg.

${ }^{62}$ Cit. after: Lew Besymenski, Lew Jelin, A. Frohn, Wallenberg war ein Doppelagent, Der Spiegel, 1996, Nr. 40, 1996, p. 201 (http://www.spiegel.de/spiegel/print/d-9095860.html; access from $15^{\text {th }}$ August 2015). The Polish translation of the article appeared in the periodical "Literatura" (1996, no. 12, pp. 38-42) titled Wallenberg - podwójny agent. However, the quality of the text is not very good.

${ }^{63}$ After the war Gàbor Kemény was passed to the communist authorities by the Americans (L. A. BezyMenskiy, op.cit., pp. 80-84).

${ }^{64}$ It was suggested that he had died during the fights (Andrzej SIELSKI, Sprawa Wallenberga, Kraków 2002, pp. 149-153). 
the Kremlin did their best to cover up the kidnapping of Raoul Wallenberg, in January 1945 Alexandra Kollontai sent the following information to the Swedish diplomat's mother, Maria Dardel: "Raoul Wallenberg and his personal belongings are under the protection of the military authorities of the USSR". ${ }^{65}$ When the Swedish government did not intervene to defend their diplomat, the Soviet ambassadress contacted Ingrid - the wife of the Minister of Foreign Affairs of Sweden Christian Günther. ${ }^{66}$

We still do not know the motives behind Kollontai's behaviour: she passed information about Raoul Wallenberg to his closest family, thereby jeopardizing her life and that of her family. Another possibility is that it was an element of Stalin's cynical game, for which evidence could also be found.

Alexandra Kollontai could have passed her message about Wallenberg to his closest family as she felt gratitude for saving her beloved Finland. She could have also been impressed by the mission of the Swedish diplomat. That is why she contacted the wife of the Swedish Foreign Minister, which was to force Stockholm to react more sharply, which, as we know, never happened. According to scholars from the Russian-Swedish group researching the history of Wallenberg, the Soviet ambassadress's actions were not accepted by the Kremlin. After some years, Kollontai's secretary Emma Lorentson testified that having returned home, Kollontai investigated Wallenberg's case and found out that he had died in a Moscow prison. Later, under coercion from the highest authorities, she spoke about the history of Wallenberg according to the propaganda policy of the USSR. Another factor which may prove the theory that the Soviet ambassadress had acted independently in wanting to help Wallenberg is the fact that after Raoul's whereabouts had been revealed, Alexandra Kollontai was dismissed from her post and transported to Moscow despite suffering from pneumonia. In 1952 the authorities attempted to accuse her of participating in an imperialist conspiracy, but she died before being arrested. ${ }^{67}$

Still, the above-mentioned reasoning could be overturned. Before Alexandra Kollontai contacted Raoul's mother, the Swedish ambassador in Moscow

${ }^{65}$ Maria Maj von Dardel (1891-1979), de domo Wising. After the death of her first husband, Raoul's father, Oscar Wallenberg, in 1912 she brought up her son alone. Her second husband was Fredrik von Dardel (1885-1979).

${ }^{66}$ Raoul Wallenberg. Redosvisningen från den svensk-ryska arbetsgruppen, p. 82; Ett diplomatiskt misslyckande. Fallet Raoul Wallenberg, p. 79. Christian Günther (1886-1966) - Swedish diplomat and Minister of Foreign Affairs in the years 1939-1945. His wife was Ingrid Günther (1888-1981).

${ }^{67}$ Raoul Wallenberg. Redosvisningen från den svensk-ryska arbetsgruppen, pp. 82-83; K. Hauge, op.cit., pp. 246-247; Stéphane Courtois, Nicolas Werth, Jean-Luis Panne, Andrzej Paczkowski, Karel Bartosek, Jean-Luis Margolin [et al.], Czarna ksiega komunizmu, Warszawa 1999, p. 238. 
Staffan Söderblum ${ }^{68}$ sent a message about the secretary of the diplomatic post being arrested in Budapest by the soldiers of the Red Army. It is known that the arrested person was a Soviet agent. The authorities of the USSR closely monitored all the reactions of Stockholm to the news about the abducted diplomat. The information transmitted by Alexandra to Raoul's family were to protect the valuable agent. On the other hand, the question arises as to whether Stalin's people would transmit such important information to another state through such a valuable agent. ${ }^{69}$

It was not so obvious that the reason for Kollontai's dismissal from the post in Stockholm was her passing of information about Wallenberg to his closest family. Alexandra Kollontai was nominated for the Peace Nobel Prize for her contribution to the negotiations between Finland and the Soviet Union. This information irritated Stalin, who wanted to receive the prize himself. As a result of his fury, the ambassador in Sweden was changed. ${ }^{70}$

In the same vein, the accusation against Kollontai of espionage was not necessarily connected with the case of Raoul Wallenberg. The information about Kollontai's contacts with Raoul's mother appeared in the first publications devoted to the secretary of the Swedish embassy. The accusations directed at her appeared shortly before her death in 1952. It should be emphasized that the investigators believed that she cooperated with the English secret service, not the Swedish one. ${ }^{7}$

The Swedish biographer of Raoul Wallenberg, Bengt Jagenfeldt, generated a bizarre theory, according to which Marcus and Jacob, using their contact in the USSR, murdered their nephew. The thesis of this Scandinavian journalist can be easily criticized. It is hard to presume that after the war Raoul could take over the business empire as it would have undermined the position of the heads of the clan. He fails to explain why Alexandra contacted Raoul's family members. Was it a blackmail attempt on the part of the Soviet authorities? ${ }^{72}$

${ }^{68}$ Staffan Söderblum (1900-1985) - Swedish diplomat, ambassador in Moscow in the years 1944-1946; later he was the head of the post in Bejing in the years 1951-1952.

${ }^{69}$ Mysteriet Wallenberg fortalt i tekst, billeder og dokumenter, red. Leon Nikunin, Jacob W. F. SundBerg, [n.p.] 2010, p. 111; Raoul Wallenberg. Redosvisningen från den svensk-ryska arbetsgruppen, p. 87; Krister WäLBACK, Raoul Wallenberg och synen på Sovjet 1944-1947, [in:] Till en konstnärjarssjäl. En vanbok till Stig Ramel, red. S. RAmEL, Stockholm 2002, p. 124.

${ }^{70}$ Elina Katainen, Arbeid, fred, fri kjaerlighet. Kollontaj sett med finske øyne, [in:] Revolusjon, kjaerlighet, diplomati. Alexandra Kollontaj og Norden, p. 250.

${ }^{71}$ Rudolph PHILIPP, Kämpe för Humanitet, Stockholm 1947, p. 24; Lever Raoul Wallenberg, Året Runt from $21^{\text {th }}$ August 1947.

${ }^{72}$ Bengt Jangfeldt, The Hero of Budapest: The Triumph and Tragedy of Raoul Wallenberg, New York 2014, pp. 314-360. 
It must be underlined that, having returned to the USSR, Alexandra Kollontai did not contact the Wallenberg family any more. It was dangerous for her as the Soviet propaganda began to present these Swedish businessmen as ferocious capitalist and enemies of socialism. ${ }^{73}$

Alexandra Kollontai established negotiations between the USSR and SEB about the return of the gold deposited in the Swedish bank by the Russian Provisional Government in 1930. It was then that she met the Wallenbergs for the first time. She spent holidays in their hotel, which could be evidence of her more amicable relationship with the family.

During the Winter War, Kollontai did not cooperate with either Marcus or Jacob. This remained unchanged until the Third Reich invaded the USSR. It was then that Marcus and Alexandra started to cooperate in order to withdraw Finland from the war. The elderly Russian ambassadress and the Swedish financier were connected diplomatically, but they also found common ground. Still, Kollontai as the Soviet diplomatic representative sent regular reports to Moscow about her her friend's moves.

Alexandra Kollontai also contacted other members of the Wallenberg family - Raoul and his mother. Alexandra's attitude towards the closest family of the Swedish diplomat was astonishing. However, it is hard to establish whether this resulted from her good intentions or if it was the result of Stalin's cynical game.

Kollontai's contacts with the Wallenberg family were mainly professional. Still, Alexandra managed to establish friendly relations with the representatives of this Swedish banking family. It must be underlined that without the mutual involvement of the Soviet ambassadress and Marcus, the history of Finland could have been totally different.

We still do not know what had happened behind the scenes when Kollontai met Raoul Wallenberg. We also do not know what united them: a willingness to help the victims of the Holocaust, business negotiations or espionage activity. Unfortunately, it is not possible to answer these questions as long as the majority of the Russian archival sources devoted to the secretary of the Swedish embassy in Budapest remain classified.

(trans. by Agnieszka Chabros)

Received $17^{\text {th }}$ October 2015

Received in revised form $17^{\text {th }}$ February 2017

Accepted $30^{\text {th }}$ June 2017

${ }^{73}$ Raoul Wallenberg. Redosvisningen från den svensk - ryska arbetsgruppen, p. 62. 
Dr Jan Ratuszniak

Institute of History

University of Łódź

e-mail: janratuszniak@wp.pl

\author{
Contact Between Alexandra Kollontai \\ AND The Wallenberg FAMily (1930-1945)
}

\title{
Summary
}

Key words: WWII, Sweden, the USSR, Finland, Raoul Wallenberg, the Winter War

The article presents the history of the contact between Alexandra Kollontai and the Wallenberg family. The first meetings between the Russian diplomat and the influential family of Swedish bankers took place in the 1930s during the negotiations concerning the return of the Russian gold kept by the bank owned by the Wallenbergs. Prior to the outbreak of WWII this first female ambassador met members of the Wallenberg family in a sanatorium. Undoubtedly, the encounters of Marcus Wallenberg with Alexandra Kollontai affected the situation of Finland during WWII. Without their common involvement in the case, the history of Finland during the war with the USSR might have been totally different. The backstage information about the relationship between Alexandra and Raoul Wallenberg is also very interesting. Unfortunately, we are unable to answer many questions and clarify doubts as long as the majority of the Russian archives devoted to the secretary of the Swedish diplomat remain secret.

\section{Die Kontakte von Alexandra Kollontai ZUR FAMilie Wallenberg (1930-1945)}

\section{Zusammenfassung}

Schlüsselwörter: Zweiter Weltkrieg, Schweden, Sowjetunion, Finnland, Raoul Wallenberg, Kalter Krieg

Im Artikel geht es um die Kontakte von Alexandra Kollontai zur Familie Wallenberg. Zu den ersten Begegnungen zwischen der diplomatischen Vertreterin Russlands und dem einflussreichen schwedischen Bankiersgeschlecht kam es in den dreißiger Jahren des 20. Jahrhunderts bei Gesprächen, bei denen es um die Rückgabe von russischem Gold ging, das in der Bank aufbewahrt wurde, die den Wallenbergs gehörte. Vor dem Ausbruch des Zweiten Weltkriegs traf sich die erste Frau, die ein Botschafteramt bekleidete, mit Vertretern der Familie Wallenberg in einem Sanatorium. Mit 
Sicherheit hat das Treffen von Marcus Wallenberg mit Alexandra die Lage Finnlands während des Zweiten Weltkriegs mitgeprägt. Ohne ihr gemeinsames Engagement hätten die Schicksale Finnlands in der Zeit der Auseinandersetzung mit der Sowjetunion ganz anders aussehen können. Sehr interessant sind auch die Hintergründe der Beziehung, die die berühmte Revolutionärin mit Raoul Wallenberg verband. Da ein bedeutender Teil der russischen Archive, in denen sich Informationen zum Sekretär der schwedischen Diplomatie finden könnten, weiterhin geheim ist, lassen sich die vielen Fragen und Zweifel in diesem Bereich leider nicht beantworten.

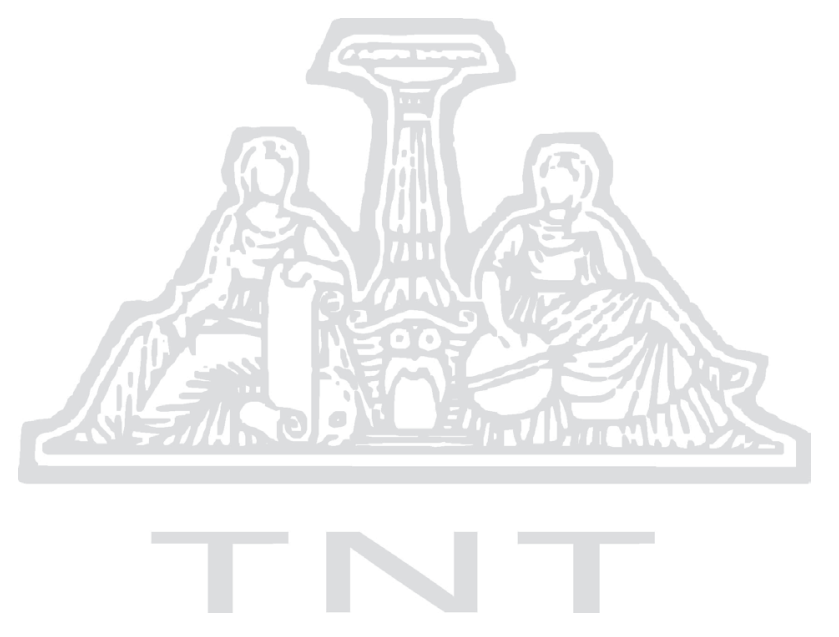


Jan Ratuszniak

\section{BiBLIOGRAPHY}

Agrell, Wilhelm. Skuggor runt Wallenberg. Uppdrag i Ungern 1943-45. Lund: Historiska Media, 2006.

Birstein, Vadim J. Smiersz. Tajna broń Stalina. Sowiecki kontrwywiad wojskowy podczas II wojny światowej. Trans. Tomasz Fiedorek. Kraków: Wydawnictwo Arkadiusz Wingert, 2013.

Body, Marcel. "Alexandra Kollontai”. Preuves (1952) no. 14: 12-24.

Courtois, Stéphane [et al.]. Czarna księga komunizmu. Zbrodnie, terror, prześladowania. Intro. Krystyna Kersten, trans. Krzysztof Wakar [et al.]. Warszawa: Prószyński i S-ka, 1999.

Ett diplomatiskt misslyckande. Fallet Raoul Wallenberg och den svenska utrikesledningen. Stockholm: Fritze, 2003.

Gilmour, John. Sweden, the Swastika and Stalin. The Swedish Experience in the Second World War. Edinburgh: Edinburgh University Press, 2012.

Jangfeldt, Bengt. The Hero of Budapest: The Triumph and Tragedy of Raoul Wallenberg. London-New York: I. B. Tauris, 2014.

Jaworski, Paweł. “Raoul Wallenberg - co nowego?”. Dzieje Najnowsze 44/3 (2013): 121-129.

Jerofejev, Vladimir I. "Vid den sovjetiska ambassaden i Stockholm 1942-1945". In: Revolusjon, kjorlighet, diplomati. Aleksandra Kollontaj og Norden, ed. Yngvild Sørbye. Oslo: Unipub, 2008.

Kastory, Andrzej. Finlandia w polityce mocarstw 1939-1940. Kraków: Wydawnictwo Naukowe WSP, 1993.

Kastory, Andrzej. Złowrogie sąsiedztwo. Rosyjska polityka wobec europejskich państw ościennych w latach 1939-1940. Kraków: Wydawnictwo Naukowe WSP, 1998.

Katainen, Elina. "Arbeid, fred, fri kjaerlighet. Kollontaj sett med finske øyne". In: Revolusjon, kjoerlighet, diplomati. Aleksandra Kollontaj og Norden, ed. Yngvild Sørbye. Oslo: Unipub, 2008.

Kollontaj, Vladimir M. "Minnen Av famor". In: Revolusjon, kjorlighet, diplomati. Aleksandra Kollontaj og Norden, ed. Yngvild Sørbye. Oslo: Unipub, 2008.

Lindgren, Håkan. Jacob Wallenberg 1892-1980. Stockholm: Atlantis, 2007.

Nikunin, Leon, Jacob W. F. Sundberg. Mysteriet Wallenberg fortalt i tekst, billeder og dokumenter. Viby: Panorama, 2010.

Olsson, Ulf. Furthering a Fortune, Marcus Wallenberg. Swedish Banker and Industrialist 1899-1982. Stockholm: Ekerlid, 2001.

Paasikivi, Juho K. J.K. Paasikivis dagböcker 1941-1944. Samtal i ond tid. Stockholm: Tiden, 1991.

Philipp, Rudolph. Kämpe för Humanitet. Stockholm: Fredens Förl., 1947.

Pipes, Richard. Rosja Bolszewików. Trans. Władysław Jeżewski. Warszawa: Wydawnictwo Magnum, 2007.

Pirogowicz, Krystyna. „Co się stało z Raoulem Wallenbergiem? Losy zaginionego dyplomaty w świetle najnowszych badań”. Zapiski Historyczne 73/1 (2008): 83-97.

Porter, Cathy. Alexandra Kollontai. A biography. London: Haymarket Books, 2014. 
Contact Between Alexandra Kollontai and the Wallenberg Family (1930-1945)

Raoul Wallenberg. Redovisning från den svensk-ryska arbetsgruppen. Stockholm: UD, 2000.

Ratuszniak, Jan. “Russkiye, Polyaki, Finny? Etnicheskaya identichnost' sem'i Aleksandry Kollontay”. In: Vade Nobiscum. Materiały Studenckiego Koła Naukowego Historyków Uniwersytetu Łódzkiego, vol. 13, eds. Konrad Banaś, Robert Stasiak, 259-266. Łódź: Uniwersytet Łódzki, 2014.

Sielski, Andrzej. Sprawa Wallenberga. Kraków: Arcana, 2002.

Światek, Lilianna. „Aleksandra Kołłontaj na placówce w Meksyku (1926-1927)”. Acta Universitatis Lodziensis. Folia Historica 76 (2003): 113-130.

Szordykowska, Barbara. Historia Finlandii. Warszawa: Wydawnictwo Trio, 2011.

Thorsell, Staffan. Mein lieber Reichskanzler! Sveriges kontakter med Hitlers rikskansli. Oslo: Bonnier Fakta, 2007.

“Wallenberg war ein Doppelagent”. Der Spiegel, 30.09.1996. Access: 15.08.2015. http:// www.spiegel.de/spiegel/print/d-9095860.html

Wälback, Krister. "Raoul Wallenberg och synen på Sovjet 1944-1947”. In: Till en konstnärssjäl. En vänbok till Stig Ramel, ed. Lars Gyllensten. Stockholm: Atlantis, 2002.

Bezymenskiy, Lev A. Budapeshtskaya missiya. Raul' Vallenberg. Moskva: Kollektsiya „Sovershenno Sekretno", 2001.

Dyullen, Sabin. Stalin i yego diplomaty. Sovetskiy Soyuz i Yevropa. 1930-1939 gg. Moskva: ROSSPEN, 2009.

Ken, Oleg, Aleksandr Rupasov, Lennart Samuyel'son. Shvetsiya v politike Moskvy 1930-1950-ye gody. Moskva: Rossiyskaya politicheskaya entsiklopediya, 2007.

Klinge, Matti. Imperskaya Finlyandiya. Sankt-Peterburg: Kolo, 2005.

Kollontay, Aleksandra M. Diplomaticheskiye dnevniki: 1922-1940, vol. 1-2. Moskva: Akademia, 2001.

Lorentson, Emma. “A. M. Kollontay v Shvetsii”. Novaya i Noveyshaya Istoriya (1966) no. 1: 105-111.

Olesin, Mikhail I. Pervaya v mire. Biograficheskiy ocherk ob A. M. Kollontay. Moskva: Izd-vo polit. lit-ry, 1990.

Repnevskiy, Andrey V. SSSR-Norvegiya: ekonomicheskiye otnosheniya mezhvoyennogo dvadtsatiletiya. Arkhangel'sk: Universiteta im. M.V. Lomonosova, 1998.

Sinitsyn, Yelisey. Rezident svidetel'stvuyet. Moskva: Geya, 1996.

Trush, Mikhail. Ot politiki revolyutsionnoy bor'by $k$ pobedam na diplomaticheskom fronte: zhiznennyy put' Aleksandry Kollontay: „Zolotaya vetv' diplomatii Rossii”. Moskva: Librokom, 2013. 